\title{
Long-Distance Oceanic Movement of a Solitary Dugong (Dugong dugon) to the Cocos (Keeling) Islands
}

\author{
Jean-Paul A. Hobbs, ${ }^{1}$ Ashley J. Frisch, ${ }^{1}$ Jay Hender, ${ }^{2}$ and Justin J. Gilligan ${ }^{3}$ \\ ${ }^{\prime}$ Australian Research Council Centre of Excellence for Coral Reef Studies, and School of Marine and Tropical Biology, \\ James Cook University, Townsville, Queensland, 4811, Australia; E-mail: Jean-Paul.Hobbs@jcu.edu.au \\ ${ }^{2}$ Fisheries and Marine Sciences Programme, Bureau of Rural Sciences, GPO Box 858, \\ Canberra, Australian Capital Territory, 2601, Australia \\ ${ }^{3}$ Aquatic Ecosystems Research, New South Wales Department of Primary Industries-Fisheries, \\ Private Bag 1, Nelson Bay, New South Wales, 2315, Australia
}

\begin{abstract}
In this paper, we report on the arrival of a small ( $2 \mathrm{~m}$ long) male dugong (Dugong dugon) to the Cocos (Keeling) Islands $\left(12^{\circ} 12^{\prime} \mathrm{S}, 96^{\circ} 54^{\prime} \mathrm{E}\right)$, Indian Ocean. The dugong arrived in June 2002 after travelling more than $1,000 \mathrm{~km}$ across deep open ocean, during which time it would have been vulnerable to predation and presumably unable to feed. This is the longest recorded dugong movement and demonstrates that dugongs have the capacity to make long-distance oceanic movements to colonise distant, unoccupied locations. The solitary dugong has remained at the Cocos Islands for at least four years and exhibits unusual habitat use and behaviour; it frequently occupies deep water on the edge of the coral reef and interacts with SCUBA divers.
\end{abstract}

Key Words: dugong, Dugong dugon, Cocos (Keeling) Islands, movement, dispersal, re-colonisation, habitat use, behaviour

\section{Introduction}

Dugongs (Sirenia: Dugong dugon [Müller, 1776]) inhabit shallow, tropical, and subtropical waters ranging from the east coast of Africa to Vanuatu (Nishiwaki \& Marsh, 1985). Dugongs appear to be most abundant in coastal embayments and may occur alone or in groups of up to several hundred individuals (Marsh et al., 2002). The IUCN classifies dugongs as "vulnerable," based on evidence of declining local abundances and areas of occupancy (Marsh et al., 2002). Isolated populations appear to be particularly vulnerable, and local extinctions have been reported at several island locations (Husar, 1975). These local extinctions have resulted in a geographic distribution consisting of spatially segregated relict populations throughout much of its range (Marsh et al., 2002).
Understanding the movement capabilities of dugongs is important for their conservation, particularly in relation to population connectivity and re-colonisation.

The Cocos (Keeling) Islands ( $\left.12^{\circ} 12^{\prime} \mathrm{S}, 96^{\circ} 54^{\prime} \mathrm{E}\right)$ form an isolated, oceanic atoll that is located in the northeastern Indian Ocean, approximately 1,000 $\mathrm{km}$ southwest of Java, Indonesia (Figure 1). The atoll rises steeply out of deep water $(>4 \mathrm{~km})$ and has an extensive lagoon, with more than 2,600 ha of shallow seagrass meadows that include species of Syringodium, Thalassia, and Thalassodendron (Williams, 1994; Hender et al., 2001). This shallow seagrass habitat appears suitable for dugongs, and the Islands were once part of the dugong's historical range; however, in 1970, it was reported that dugongs no longer occur at the Islands (Snow, 1970, in Husar, 1975). Since 1970, there have been only two confirmed sightings of dugongs at the Cocos Islands ( ca 1989 and 1998, John CluniesRoss \& Wendy Murray, pers. comm.). On both occasions, a solitary dugong was seen for a short period of time before disappearing. In this paper, we report on the long-distance oceanic movement of a dugong to the Cocos Islands. We also describe the unusual behaviour and habitat associations of this solitary dugong based on our personal observations and interviews with the local people.

\section{Materials and Methods}

From July to September 2005, we visited the Cocos Islands to investigate the movement patterns, habitat associations, and behaviour of the resident dugong. Interviews were conducted with the local people to determine the approximate arrival date and subsequent movement patterns of the dugong. The local subsistence fishermen and dive operators have an intimate knowledge of marine life at the Islands. Discussions with these people provided information on sightings around 


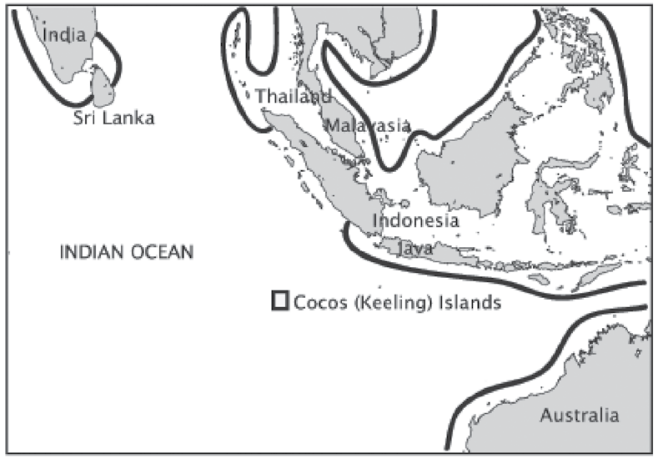

Figure 1. The location of the Cocos (Keeling) Islands in the northeastern Indian Ocean; the present geographic range of dugong in this region is represented by black outline (re-drawn from Marsh et al., 2002).

the atoll and patterns of habitat use. Similarly, SCUBA divers shared their knowledge of the dugong's behaviour, based on their own underwater observations. We also conducted 15 dives at the northern dive site (Figure 2) to make underwater observations of the dugong's behaviour. To quantitatively describe the habitat used by the dugong, the benthic surface at the northern dive site was surveyed using five replicate $3-\mathrm{m}$ line intercept transects at each of three depths $(1,5$, and $20 \mathrm{~m})$.

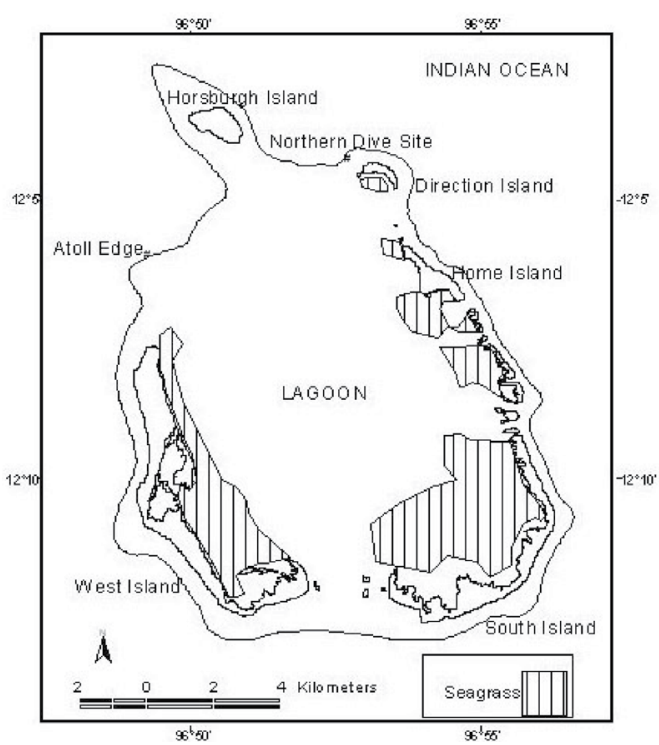

Figure 2. Site map of the Cocos (Keeling) Islands (main atoll) illustrating the location of the northern dive site and the distribution of seagrass beds; the atoll edge is indicated by the solid line. Seagrass data are taken from Williams, 1994, and Hender et al., 2001.

\section{Results}

In June 2002, a dugong arrived at the Cocos Islands having travelled at least $1,000 \mathrm{~km}$ through the open ocean. Since its arrival, the dugong has been observed on a regular basis, except for a 3mo period (January to March 2003) when it was assumed to have temporarily left the atoll (Dieter Gerhard \& Karen Willshaw, pers. comm.). The dugong has remained at the atoll for the past four years (June 2002 to 2006). During our underwater observations in 2005, the dugong appeared healthy (i.e., without obvious signs of disease or injury) and was approximately $2 \mathrm{~m}$ in length. The position of the genital slit relative to the anus and umbilicus indicated that the dugong was a male (Figure 3 ) and probably approaching maturity as male dugongs mature at body lengths between 1.9 and $2.57 \mathrm{~m}$ (Marsh et al., 1984; Kwan, 2002).

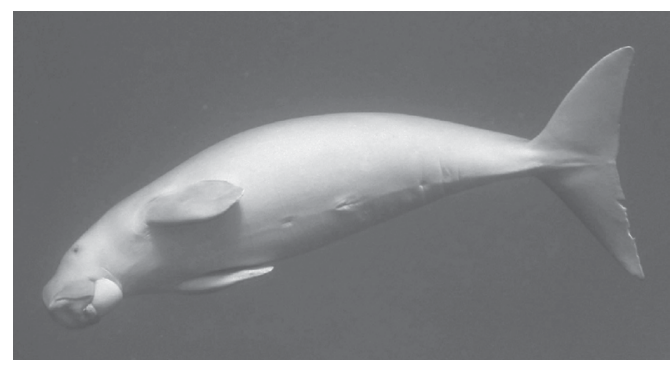

Figure 3. Ventral view of the solitary dugong at the Cocos (Keeling) Islands; the position of the genital slit relative to the anus and umbilicus indicates that this individual is a male. (Photo by Karen Willshaw)

According to the local people, the dugong was most commonly sighted on the northern edge of the atoll adjacent to Direction Island, although it was occasionally seen in the lagoon (e.g., on seagrass beds near Home Island) (Figure 2). At the northern edge of the atoll, the coral reef extends approximately $300 \mathrm{~m}$ seaward from Direction Island to a depth of $18 \mathrm{~m}$ at the atoll edge before dropping rapidly to the abyssal plain. The habitat at this site was comprised of turfing algae (42 to $53 \%$ ) and sand (17 to $40 \%$ ), with small areas of live coral and crustose coralline algae (Table 1). No seagrasses were recorded in the transects or observed in the vicinity of the transects.

We conducted 15 dives at the northern dive site. We heard the dugong's distinct vocalisation on eight occasions and saw the dugong on five of these occasions. Twice, the dugong approached us (within $0.5 \mathrm{~m}$ ) and interacted with us for 10 to $20 \mathrm{~min}$. The dugong has also been observed swimming with manta rays and dolphins (Karen Willshaw \& Dieter Gerhard, pers. comm.). We 
Table 1. The mean percentage of habitat types at the site most frequented by the dugong (northern dive site); data presented from three depths $(1,5$, and $20 \mathrm{~m})$.

\begin{tabular}{lcccccc}
\hline Depth & $\begin{array}{c}\text { Crustose } \\
\text { coralline algae }\end{array}$ & Turf algae & Hard coral & Soft coral & Coral rubble & Sand \\
\hline $1 \mathrm{~m}$ & 6.67 & 52.67 & 1.00 & 0.00 & 0.00 & 39.67 \\
$5 \mathrm{~m}$ & 16.33 & 42.33 & 20.33 & 0.00 & 4.00 & 17.00 \\
$20 \mathrm{~m}$ & 18.00 & 52.33 & 0.33 & 2.00 & 0.00 & 27.33 \\
\hline
\end{tabular}

observed the dugong swimming within approximately $4.0 \mathrm{~m}$ of several grey reef sharks $(1.8 \mathrm{~m}$ in length) (Carcharhinus amblyrhynchos), and the dugong's and sharks' behaviour did not change when in proximity. The dugong periodically swam off the edge of the atoll into the open ocean.

\section{Discussion}

The arrival of a dugong at the Cocos Islands provides important insights into the movement capabilities of this vulnerable species. Tagging studies reveal that dugongs are capable of travelling up to $625 \mathrm{~km}$ in a single movement (see Sheppard et al., 2006, and references therein). The dugong's movement to the Cocos Islands demonstrates that they are capable of travelling much greater distances, however. The nearest dugong population to the Cocos Islands is in Ujong Kulon National Park (Java, Indonesia) (Marsh et al., 2002), which is over $1,000 \mathrm{~km}$ away. Alternatively, the dugong may have come from Australia, India, Malaysia, Sri Lanka, or Thailand. These populations are more than 2,000 km from the Cocos Islands.

Most recorded movements of dugongs occur along shallow coastal regions (Marsh et al., 2002; Sheppard et al., 2006). The dugong at the Cocos Islands must have swum at least $1,000 \mathrm{~km}$ through open ocean that was greater than $4 \mathrm{~km}$ deep. Although rare, oceanic movements of dugongs have been recorded elsewhere over shorter distances (up to $425 \mathrm{~km}$; Marsh et al., 2002). The dugong's oceanic movement to the Cocos Islands provides empirical support for occasional longdistance dispersal events as suggested by molecular studies (McDonald, 2006) and the species' historical geographic range (Husar, 1975).

Dugongs typically undertake movements in response to social cues or changes in water temperature and/or food availability (Anderson, 1982; Marsh et al., 2002; Sheppard et al., 2006), and such movements are aided by a knowledge of the surrounding area and an ability to navigate (Sheppard et al., 2006). The motive for travelling to the Cocos Islands is unclear since the dugong would not have encountered any shallow water habitat during its journey, thus making it vulnerable to predation and unable to feed. Dugongs undertaking long-distance movements in coastal environments often track the substrate (Sheppard et al., 2006); however, this is unlikely to occur while travelling to the Cocos Islands. The deep waters $(>4 \mathrm{~km})$ surrounding the Islands are probably beyond the diving abilities of dugongs (Marsh et al., 2002; Chilvers et al., 2004; Sheppard et al., 2006), and they lack any obvious physical landmarks or other navigational features. Detection of the Islands would have also been difficult due to their small size, isolation, and the absence of other dugongs. Nonetheless, it is evident that dugongs are capable of colonising distant and unoccupied locations, even if it involves traversing deep ocean habitat.

Although dugongs are usually observed in shallow, coastal, seagrass areas, the dugong at the Cocos Islands is most commonly sighted on the steep, coral reef at the northern edge of the atoll. At this location, the dugong periodically swam off the edge of the atoll into the open ocean and appeared unbothered by the high densities of reef sharks that occurred there (Hender et al., 2001; Robbins et al., 2006). The reason for the dugong frequenting the northern edge of the atoll is unlikely related to food because this area lacked seagrass. The dugong's presence at the atoll edge may be partly explained by an attraction to SCUBA divers, as this site is an established dive site, and solitary dugongs have been known to interact with humans elsewhere (Adam, 1998).

In conclusion, the arrival of a dugong to the Cocos Islands demonstrates that dugongs have the capacity to make long-distance oceanic movements to colonise distant and unoccupied locations. Considering local extinctions have occurred on other less-isolated islands (Husar, 1975), it is promising that these locations can potentially be re-colonised by natural dispersal and that populations may become established if the original cause of extinction is addressed.

\section{Acknowledgments}

We are grateful for the information supplied by the Cocos Islands community, especially Karen Willshaw and Dieter Gerhard. Thanks to John Clunies-Ross and Geof Christie for logistical 
support. We thank Peter Corkeron, Dieter Gerhard, Sebastian Hobbs, Helene Marsh, Brenda McDonald, Wendy Murray, James Sheppard, Robert Thorn, and Karen Willshaw for constructive comments that helped improve the manuscript. Images were provided courtesy of Karen Willshaw.

\section{Literature Cited}

Adam, S. (1998, October). Dugong-human interactions. Sirenews, 30, 13-16.

Anderson, P. K. (1982). Studies of dugongs at Shark Bay, Western Australia. I. Analysis of population size, composition, dispersion and habitat use on the basis of aerial survey. Australian Wildlife Research, 9, 69-84.

Chilvers, B. L., Delean, S., Gales, N. J., Holley, D. K., Lawler, I. R., Marsh, H., et al. (2004). Diving behaviour of dugongs, Dugong dugon. Journal of Experimental Marine Biology and Ecology, 304, 203-224.

Hender, J., McDonald, C. A., \& Gilligan, J. J. (2001). Baseline surveys of the marine environments and stock size estimates of marine resources of the south Cocos (Keeling) Atoll (0-15 m), Eastern Indian Ocean. Canberra, Australia: Fisheries Resources Research Fund. 43 pp.

Husar, S. (1975). A review of the literature of the dugong, Dugong dugon. In Fish and wildlife services wildlife research report: No. 4 (pp. 1-30). Washington, DC: U.S. Department of the Interior.

Kwan, D. (2002). Towards a sustainable indigenous fishery for dugongs in Torres Strait: A contribution of empirical data and process. Ph.D. dissertation, James Cook University, Townsville, Australia. 283 pp.

Marsh, H., Heinsohn, G. E., \& Marsh, L. M. (1984). Breeding cycle, life history and population dynamics of the dugong, Dugong dugon (Sirenia: Dugongidae). Australian Journal of Zoology, 32, 767-788.

Marsh, H., Penrose, H., Eros, C., \& Hugues, J. (2002). Dugong: Status report and action plans for countries and territories. In UNEP early warning and assessment report series 1 . Cambridge, UK: United Nations Environment Programme (UNEP). 162 pp.

McDonald, B. J. (2006). Population genetics of dugong around Australia: Implications of gene flow and migration. Ph.D. dissertation, James Cook University, Townsville, Australia. 183 pp.

Nishiwaki, M., \& Marsh, H. (1985). The dugong, Dugong dugon (Müller, 1776). In S. H. Ridgway \& R. J. Harrison (Eds.), Handbook of marine mammals, Vol. 3 (pp. 1-31). London: Academic Press. 362 pp.

Robbins, W. D., Hisano, M., Connolly, S. R., \& Choat, J. H. (2006). Ongoing collapse of coral-reef shark populations. Current Biology, 16, 2314-2319.

Sheppard, J. K., Preen, A. R., Marsh, H., Lawler, I. R., Whiting, S. D., \& Jones, R. E. (2006). Movement heterogeneity of dugongs, Dugong dugon (Müller) over large spatial scales. Journal of Experimental Marine Biology and Ecology, 334, 64-83.

Snow, D. W. (1970). The eastern Indian Ocean islands: A summary of their geography, fauna and flora. World Conservation Union (IUCN) Publication N. S. Morges, 17, 212-223.

Williams, D. G. (1994). Marine habitats of the Cocos (Keeling) Islands. Atoll Research Bulletin, 406, 1-10. 
Reproduced with permission of the copyright owner. Further reproduction prohibited without permission. 